\title{
Biodiversity offsetting in England: governance rescaling, socio-spatial injustices, and the neoliberalization of nature
}

\author{
Evangelia Apostolopoulou \\ Department of Geography, University of Cambridge, CB2 3EN, Cambridge, UK \\ Correspondence to: Evangelia Apostolopoulou (ea367@cam.ac.uk)
}

Received: 28 September 2015 - Accepted: 2 February 2016 - Published: 1 March 2016

\begin{abstract}
In this paper, I use primary empirical data obtained through interviews in selected case studies around England to shed light on the neoliberal character of biodiversity offsetting, its interrelationship with governance rescaling processes, and the way the latter influences the distribution of the costs and benefits of biodiversity offsetting policies. My results show that biodiversity offsetting in England has been a reactionary neoliberal policy whose implementation has so far been characterized by important deficits from an environmental and socio-spatial justice perspective.
\end{abstract}

\section{Introduction}

The concepts of biodiversity offsetting and no net loss (NNL) are becoming increasingly important in biodiversity conservation strategies worldwide (Madsen et al., 2011). The core idea of offsetting is that losses to biodiversity in one place (and at one time) can be compensated by creating equivalent biodiversity gains elsewhere (Apostolopoulou and Adams, 2015a).

Offsetting aims to resolve the contradiction between economic growth and environmental protection by relocating ecological compensation across space and time to facilitate, and in some cases even boost, development. The implementation of biodiversity offsetting is deeply intertwined with processes of "governance rescaling", meaning the rearticulation of political scales either downwards to regionalist/localist arrangements, or upwards to larger social and political levels (e.g. to the EU or global levels) as well as outwards to wider networks of private capital (Apostolopoulou et al., 2014; Harvey, 2005; Swyngedouw, 2004). Even though emphasis has been given to the decisive role of governance rescaling in the articulation of green markets within existing regulatory regimes, the majority of existing studies have focused on the emerging alliances between corporations, donor agencies, governments, and environmental organizations at a global level or in the developing world. The interrelation- ship between biodiversity governance and the establishment of market environmentalism in biodiversity policy and governance in Europe has so far received less attention (see also Apostolopoulou et al., 2014).

In this short paper, I aim to shed light on the neoliberal character of biodiversity offsetting, its interrelationship with governance rescaling processes, and the way the latter influences the distribution of the costs and benefits of offsetting policies. I pay particular attention to the fact that biodiversity offsetting remakes non-human nature by enabling the spatial and temporal relocation of ecological losses and gains as well as to the implications of this relocation for environmental and socio-spatial justice.

\section{Case study country and methodology}

My case study country is the UK: a country providing a relevant context for this research given its key role at both EU and global levels in the emerging "biodiversity economy". Biodiversity offsetting has received increasing policy attention in the UK after the 2008 financial crash. According to the governmental rhetoric offsetting had the potential to resolve the contradiction between economic development and conservation without any actual change in economic growth patterns. Key to the latter was the simplification of ecological assessments and the introduction of a new "market" in 
ecological compensation. As we read in the Foreword of the Green Paper published in September 2013 by the Department for Environment, Food and Rural Affairs (Defra, 2013, p. 1):

Offsetting is a simple concept. It is a measurable way to ensure we make good any residual damage caused by development which cannot be avoided or mitigated. This guarantees there is no net loss from development and supports our ambition to achieve net gain for nature. For developers it can offer a simpler, faster way through the planning system. It can be quicker and more straightforward to agree a development's impacts and can create a ready market to supply compensation for residual damage to nature.

The Green Paper defined biodiversity offsets as "conservation activities that are designed to give biodiversity gain to compensate for residual losses" (Defra, 2013, p. 3) and clarified that "they are different from other types of ecological compensation as they need to show measurable outcomes that are sustained over time" (ibid.). Biodiversity offset trading was tested in six pilot areas (Devon; Doncaster; Essex; Greater Norwich; Nottinghamshire; Warwickshire, Coventry and Solihull) around the UK from April 2012 until April 2014.

To explore biodiversity offsetting in the UK, I used primary empirical data obtained through semi-structured and in-depth interviews in selected case studies (including both rural and urban areas) around England as well as an extensive analysis of all relevant legal and policy documents. In particular, my empirical research involved linked programmes of key actor interviews conducted at both national (UK) and local (field areas) levels. I have conducted interviews in seven case studies across England: the Essex biodiversity offsetting pilot, the Warwickshire, Coventry and Solihull biodiversity pilot, the case of Lodge Hill housing development in Kent, the case of the new high-speed rail network (HS2), biodiversity offsetting in North Tyneside (Newcastle), the case of the Thameslink project, and the case of the Coventry and Warwickshire Gateway. I have tried to include both case studies that were part of the official pilots that Defra has chosen for testing biodiversity offsetting but also areas where important conflicts have emerged because of the implementation of biodiversity offsetting.

Interviews took place in three phases: first, semi-structured interviews with selected economists, bankers, governmental and EU officials, and regulators in the UK who are involved in the establishment of biodiversity offsetting; second, semistructured interviews with selected conservation scientists and environmentalists in the UK involved in offsetting; and, third, in-depth interviews with all relevant stakeholders (e.g. local authorities, environmental administrations, private sector organizations, businesses, local community committees, NGOs) in the specific field areas mentioned above. All interviews were tape-recorded and transcribed.
Fieldwork also included elements of informal interviews and observation, participation in local meetings, and in some cases living in the areas while conducting the interviews.

Research methods to analyse the empirical data obtained are based on qualitative methodologies: the grounded-theory approach and frame analysis (Goffman, 1974; Strauss and Corbin, 1998). Frame analysis assists in unravelling the principles and assumptions underlined in political debate and action (Forsyth, 2003) whereas the principles of groundedtheory approach have been also adopted to foster the analysis of empirical insights toward innovative theory building (Strauss and Corbin, 1998; see also Apostolopoulou and Paloniemi, 2012).

Interview findings have been complemented by organizing group interviews with the goal of engaging a broad spectrum of stakeholders, including local communities, in a participatory assessment process to contribute in disseminating research on the neoliberalization of nature to society. The latter will be further supported by the organization of a scholars-activist conference in June 2016 in Cambridge (http://conservationandtransformation.com). One of the main topics that the conference will address will be the social, ecological, cultural, and economic impacts of biodiversity offsetting and more generally of biodiversity markets (payments for ecosystem services, carbon offsetting, etc.). One of its key goals is to facilitate an in-depth dialogue between scholars and activists, including, inter alia, people from around the UK who participated in this research and are resisting the implementation of biodiversity offsetting in their areas.

\section{Results and discussion}

Despite the increasing attempts of biodiversity offsetting's proponents in the UK to present it as a rational solution to the longstanding problems of the planning system, an opinion that has been clearly expressed in our interviews by some state officials and consultants, offsetting gained popularity in the wider context of a global crisis of capitalism and increasing attempts to impose a neoliberal environmental agenda. The latter has been manifested through the further deregulation and market-friendly reregulation of environment regulations, the privatization of nature assets and green spaces, and significant cuts in public funding for conservation, as well as reductions in conservation personnel (see Apostolopoulou et al., 2014; Apostolopoulou and Adams, 2015; see also Castree, 2008a, b, for an analysis of the neoliberalization of nature). Indeed, it could be argued that biodiversity offsetting in conjunction with conservation banking stands as a paradigmatic neoliberal policy, aiming at a further privatization, commodification, and financialization of non-human nature. It is also a clear manifestation of contemporary attempts to resolve the increasing environmental contradictions within the limits of capitalism. As one of the interviewees pointed out: 
Well, I agree, the key question is why launching biodiversity offsetting now? I guess because it is difficult to disregard environmental concerns, governments - including the UK government need sustainable development, they need to claim at least that they take it into account. Nowadays you have to talk about the environment; developers need a "licence" to function,... and trash! They are also afraid about the natural limits to growth - see what is happening with climate change. And of course after the 2008 banking crisis it is harder and harder to find avenues for profit. Mining and banking nomenclatures have made it clear that the reason they now look at conservation banking is for profit, big landowners see these as assets. And here is also the other side of my first point: as you need to refer to the environment when you talk about development and growth at the same time you cannot talk about environmental policies without saying e.g. this policy is going to gain 5 million pounds from e.g. pollination services. The value of nature in its own right without mentioning financial gains does not stand after the crisis as the main argument for doing biodiversity policy. And I would also add the issue of the frontiers, where to build, where to mine, the growth agenda increasingly requires going against the nature reserves.

Our empirical data also indicate that biodiversity offsetting is an indicative case of the strong interrelationship between the neoliberalization of non-human nature and governance rescaling processes. In England, specific governance arrangements have emerged to support the implementation of biodiversity offsetting from the very beginning. Therefore, the designation of the offset pilots included, inter alia, various partnerships between industries, governmental departments, environmental brokers, consultants, investors, local governments, and environmental NGOs (https://www. gov.uk/guidance/biodiversity-offsetting). These partnerships have been formulated to support the designation of the pilots, and one of their key goals was to attract developers to be actively involved in offsetting. Similarly, biodiversity offsetting was considered as capable of creating various business opportunities for consultants, conservation banking companies, and brokers (such as the Environment Bank, see http: //www.environmentbank.com) employed to manage offsetting processes since financial expertise is required for the brokering of exchanges.

In parallel, a further shift to localist arrangements has been evident across England along with an increasing decentralization and devolution of state conservation responsibilities to regional and/or local authorities - all indications of an extensive rescaling of biodiversity governance. The interrelationship between localism and marketization has been also evident in the case of land use planning, a policy directly rele- vant to biodiversity offsetting. As Hannis and Sullivan (2012) argue the UK government's new "presumption in favour of sustainable development" aims to encourage house building and other developments by simplifying and decentralizing the planning system while protecting the natural environment (ibid., p. 2). The latter is partly to be achieved through biodiversity offsetting which aims to enable the creation of a new market in off-site mitigation, supplementing existing policies which require (in theory) on-site mitigation of the environmental impacts of development (see Hannis and Sullivan, 2012).

Overall, in biodiversity offsetting the reasons for resisting ecosystem degradation are increasingly defined in terms of profitability, manifesting not only an ideological victory for capitalism but the creation of novel spaces for its operations by potentially opening new domains for capital accumulation (see Brockington and Duffy, 2010). It is indicative that a conservation banking market might generate GBP 50 300 million per year in credits only for the UK housing industry (Duke et al., 2012). As our interviews have shown, offsetting can also be quite profitable for local governments: in the face of decreasing public budgets and increasing competition many local and regional administrations across England have been involved in biodiversity offsetting with the aim to gain profits, a typical manifestation of the way the rescaling of governance promotes the further entrepreneurial character of rural and urban places.

It is crucial to emphasize here the deficits of the whole process from the perspective of environmental and socio-spatial justice: offsetting is characterized by a rescaling of governance towards the inclusion of the private sector and the exclusion of local communities. It is a paradigmatic case of rendering conservation a matter of experts and technocrats by portraying the process as primarily "technical" and by often preventing the local community from challenging the impacts of offsetting policies since they lack the relevant scientific expertise. At the same time, it gives important powers to unaccountable institutions like private companies working as conservation brokers. Crucially, such companies have in many cases signed confidential agreements with landowners excluding completely the local community not only from participating in the process but also from receiving information about relevant developments. Conservation activities are thus becoming part of confidential commercial transactions over land for the creation of offset sites. As two interviewees noted:

First interviewee: "There were some secret negotiations between the project officer and landowners when they were looking for potential offset sires. There was an element of commercial confidentiality they told us. So we never really knew what was happening."

Second interviewee: "They were always were saying 'I have nothing to update you apart from this confidentiality agreement that we work on', so they were saying nothing actually." 
The exclusion of local people from the various negotiations between consultants, landowners, and industry representatives (either directly or indirectly in the sense that, as many interviewees pointed out, their opinion even if expressed in most cases will not change the final outcome) is indicative of a policy that is characteristically indifferent to its social implications since the spatial and temporal relocation of ecological gains and losses is primarily, and in most cases exclusively, based on ecological arguments. As one interviewee admitted:

It is true that we need more research on the social and cultural implications of offsetting. I understand this critique. But in the meantime we don't afford stopping the implementation of the policy. What we can do is hope - and commit ourselves to it - to address potential injustices in due term.

\section{Conclusion}

Biodiversity offsetting imposes a radical simplification of ecological relations transforming nature conservation to the protection of an abstract amount of biodiversity lacking locational specificity to facilitate the relocation of biodiversity gains and losses in a way that facilitates development. In this sense, it can be seen as one of the prominent contemporary manifestations of the ways in which the production of nature is not circumstantial but a conscious goal of capital (Smith, 2010, 2007).

Biodiversity offsetting is also the outcome of a profound rescaling of biodiversity governance (Apostolopoulou et al., 2014) expressed in an increasing private sector investment in conservation and market-based approaches to addressing biodiversity loss and influencing the distribution of conservation costs and benefits, access to nature, and changes in social relations (e.g. land and resource rights). It coincides in time with calls to simplify and rationalize environmental and planning legislation, minimize bureaucracy, and decrease the state's involvement - all characteristics of a rhetoric which aims to deregulate environmental legislation.

Overall, under the surface of an apparently technical process to calculate ecological equivalence, offsetting in fact establishes a new policy frame that creates socially and spatially uneven outcomes (Apostolopoulou and Adams, 2015a). In this way offsetting is inextricably linked to questions of domination and uneven access. Through biodiversity offsetting capital creates its own distinctive ecosystem, and a new rentier class of offsetting property rights is formed having control over so-called "natural" assets. Thus, it is possible to create and manipulate scarcities and to speculate on the value of these assets (Harvey, 2014) whereas local communities across the UK are being displaced from green spaces to give space to housing or infrastructure projects. In offsetting, any choice over what kinds of environments and landscapes are to be produced, and for what purposes, increas- ingly passes into narrow class control orchestrated through the market (Smith, 2010) inevitably bringing unevenness and socio-spatial injustices.

Acknowledgements. This study was supported by an individual Marie Curie Intra-European Fellowship within the 7th European Community Framework Programme (PIEF-GA-2013-622631, Conservation and Ecosystem Services in the New biodiversity Economy-CESINE).

Edited by: J. Stadler

Reviewed by: two anonymous referees

\section{References}

Apostolopoulou, E. and Adams, W. M.: Biodiversity offsetting and conservation: reframing nature to save it, Oryx, doi:10.1017/S0030605315000782, in press, 2015a.

Apostolopoulou, E. and Adams, W. M.: Neoliberal Capitalism and Conservation in the Post-crisis Era: The Dialectics of "Green" and "Un-green" Grabbing in Greece and the UK, Antipode, 47, 15-35, 2015b.

Apostolopoulou, E. and Paloniemi, R.: Frames of scale challenges in Finnish and Greek biodiversity conservation, Ecol. Soc., 17, 9 , doi:10.5751/ES-05181-170409, 2012.

Apostolopoulou, E., Bormpoudakis, D., Paloniemi, R., Cent, J., Grodzińska-Jurczak, M., Pietrzyk-Kaszyńska, A., and Pantis, J. D.: Governance rescaling and the neoliberalization of nature: the case of biodiversity conservation in four EU countries, Int. J. Sust. Dev. World., 21, 481-494, 2014.

Brockington, D. and Duffy, R.: Capitalism and conservation: the production and reproduction of biodiversity conservation, Antipode, 42, 469-484, 2010.

Castree, N.: Neoliberalising nature: the logics of deregulation and reregulation, Environ. Plann. A, 40, 131-152, 2008a.

Castree, N.: Neoliberalising nature: processes, effects, and evaluations, Environ. Plann. A, 40, 153-173, 2008b.

Defra - Department for Environment, Food and Rural Affairs: Biodiversity Offsetting in England Green Paper, available at: https://consult.defra.gov.uk/ biodiversity/biodiversity_offsetting/supporting_documents/ 20130903Biodiversityoffsettinggreenpaper.pdf (last access: 25 February 2016), 2013.

Duke, G., Dickie, I., Juniper, T., ten Kate, K., Pieterse, M., Rafiq, M., Rayment, M., Smith, S., and Voulvoulis, N.: Opportunities for UK Business that Value and/or Protect Nature's Services, Ecosystem Markets Task Force and Valuing Nature Network, GHK, London, 2012.

Forsyth, T.: Critical political ecology: the politics of environmental science, Routledge, London, 2003.

Goffman, E.: Frame analysis: an essay on the organization of experience, Harvard University Press, Cambridge, MA, USA, 1974.

Hannis, M. and Sullivan, S.: Offsetting nature? Habitat banking and biodiversity offsets in the English Land Use Planning System, Green House, UK, 2012.

Harvey, D.: A brief history of neoliberalism, Oxford University Press, Oxford, 2005. 
Harvey, D.: Seventeen Contradictions and the End of Capitalism, Profile Books, UK, 2014.

Madsen, B., Carroll, N., Kandy, D., and Bennett, G.: Update: State of Biodiversity Markets. Offset and Compensation Programs Worldwide, Forest Trends, Washington, DC, USA, 2011.

Smith, N.: Nature as accumulation strategy, in: Socialist Register 2007: Coming to Terms with Nature, edited by: Panitch, L. and Leys, C., Merlin, London, 16-36, 2007.

Smith, N.: Uneven Development, Verso, New York, 3rd edn, 2010.
Strauss, A. and Corbin, J.: Basics of qualitative research, Sage, Newbury Park, CA, 1998.

Sullivan, S.: After the green rush? Biodiversity offsets, uranium power and the "calculus of casualties" in greening growth, $\mathrm{Hu}-$ man Geography, 6, 80-120, 2013.

Swyngedouw, E.: Globalisation or "Glocalisation"? Networks, territories and rescaling, Camb. Rev. Int. Aff., 17, 25-48, 2004. 